\title{
Jacques Prévert, Octobre. Sketches et chœurs parlés pour le groupe Octobre (1932-1936)
}

\section{Emanuele Kanceff}

\section{(2) OpenEdition}

12 Journals

\section{Edizione digitale}

URL: http://journals.openedition.org/studifrancesi/9661

DOI: 10.4000/studifrancesi.9661

ISSN: 2421-5856

\section{Editore}

Rosenberg \& Sellier

\section{Edizione cartacea}

Data di pubblicazione: 1 décembre 2007

Paginazione: 695

ISSN: 0039-2944

\section{Notizia bibliografica digitale}

Emanuele Kanceff, «Jacques Prévert, Octobre. Sketches et chœurs parlés pour le groupe Octobre

(1932-1936)», Studi Francesi [Online], 153 (LI | III) | 2007, online dal 30 novembre 2015, consultato il 09 janvier 2021. URL: http://journals.openedition.org/studifrancesi/9661 ; DOI: https://doi.org/10.4000/ studifrancesi.9661

Questo documento è stato generato automaticamente il 9 janvier 2021.

\section{(c)}

Studi Francesi è distribuita con Licenza Creative Commons Attribuzione - Non commerciale - Non opere derivate 4.0 Internazionale. 


\title{
Jacques Prévert, Octobre. Sketches et chœurs parlés pour le groupe Octobre (1932-1936)
}

\author{
Emanuele Kanceff
}

\section{NOTIZIA}

JACQUES PRÉVERT, Octobre. Sketches et chours parlés pour le groupe Octobre (1932-1936). Textes réunis et commentés par André HEINRICH, Paris, Gallimard, 2007, pp. 538.

1 Chi avesse bisogno di capire meglio il senso dell'avventura comunista di Prévert, può leggere quanto egli stesso diceva in occasione della seduta surrealista del 26 novembre 1926: «J'étais révolutionnaire à sept ans. Je suis complètement incapable d'ouvrir un livre de Marx; cela m'emmerde. Là-dessus, je m'en remets à d'autres. Il serait pour moi très facile d'adhérer au PC, mais je crois que cela n'aurait aucun sens».

Vista alla luce di tale affermazione, tutta questa raccolta di testi, cospicua e molto variegata pur nel suo orientamento ortodosso, assume una diversa sfumatura. Sotto la guida vigile di André Heinrich si riuniscono in questa edizione i testi che sia stato possibile ritrovare scritti da Prévert per il gruppo Ottobre, gruppo molto variegato, cui il curatore dedica alcune note biografiche individuali, che certamente esercitò una certa influenza all'inizio degli Anni Trenta. La versione qui utilizzata è generalmente la più antica che esista: sono i testi che Suzanne Montel, membro del gruppo fin dalla fondazione, ha conservato. All'inizio di ciascun testo sono indicate la data della prima messa in scena e della pubblicazione, qualora sia avvenuta: ma non pochi sono inediti, il che aggiunge notevolmente interesse a questa edizione. Alcuni, peraltro, sono stati pubblicati in raccolte quando Prévert era ancora vivo o subito dopo la sua morte, e per questo sono stati raccolti e sono leggibili nell'edizione Pléiade delle Euvres complètes. Non si tratta, comunque, di una edizione realizzata con i criteri delle edizioni critiche, e 
ciò priva i lettori più esigenti di avere un quadro delle varianti e correzioni che, almeno per i testi inediti, sarebbe gradito. 